\title{
Keratouveitis from Euphorbia cyparissias exposure is a temporal phenomenon
}

This article was published in the following Dove Press journal:

Clinical Ophthalmology

12 June 2012

Number of times this article has been viewed

\section{David Fleischman \\ Jay J Meyer \\ W Craig Fowler}

Department of Ophthalmology, University of North Carolina

Hospitals, Chapel Hill, NC, USA
Correspondence: David Fleischman Department of Ophthalmology, University of North Carolina at Chapel Hill, 515 I Bioinformatics Building, CB 7040, Chapel Hill, NC 27599-7040, USA $\mathrm{Tel}+\mathrm{I} 9199665509$

Fax +19199661908

Email david8fleischman@gmail.com
Abstract: We present the case of an 82-year-old woman with severe keratouveitis secondary to exposure to the plant Euphorbia cyparissias during the month of August. Despite copious irrigation of both eyes, she developed a case of Euphorbia keratouveitis that was typical in its course. Exposure to plant sap from this species should be treated much like an alkaline chemical injury as the $\mathrm{pH}$ of the ocular surface may be elevated. E. cyparissias should be carefully handled as it may result in keratouveitis, especially in early autumn.

Keywords: Euphorbia cyparissias, sap, keratitis, uveitis

\section{Case report}

An 82-year-old Caucasian female with no remarkable past medical or ocular history called the on-call ophthalmologist at our institution complaining of ocular irritation and nasal discharge following gardening. She had been pulling weeds an hour prior to the development of redness and irritation of both eyes. There were no pesticides or chemicals used in the garden and she denied any direct plant contact to her eyes while gardening. She noted substantial difficulty in washing some plant sap off her hands and had been using her hands to rinse her eyes. It was recommended that she no longer use her hands to rinse her eyes and instead use a clean cup or direct water contact to continue irrigation.

Five hours later, the patient presented to the emergency department with worsening eye pain, epiphora, redness, blurred vision, photophobia, and rhinorrhea. Vision was 20/60 in the right eye and 20/30 in the left eye. Primary survey revealed bilateral hyperemic eyes. Slit-lamp examination showed conjunctival hyperemia and scattered punctate epithelial erosions of the cornea that was worse in the right eye. The remainder of the examination was unremarkable. Each eye was irrigated for 10 minutes with saline after eversion of the lids to ensure no foreign material was present. The patient, an avid gardener, remarked several times that the plant she had been pulling was of the Euphorbia genus. Further investigation into Euphorbia exposure revealed several references in the literature describing ocular toxicity and elevated $\mathrm{pH}$ secondary to exposure to the sap from this plant. ${ }^{9}$ The $\mathrm{pH}$ was measured in each eye and found to be 9 oculus dexter and 8 oculus sinister. The eyes were irrigated for an additional 20 minutes, and subsequent $\mathrm{pH}$ measurements were 7 in both eyes. She was started on moxifloxacin drops three times a day oculus uterque with follow-up within 24 hours.

On day 2, her vision in the right eye had decreased to count fingers at 4 feet and she was found to have a large epithelial defect (Figure 1A and B) and 3+ anterior chamber 

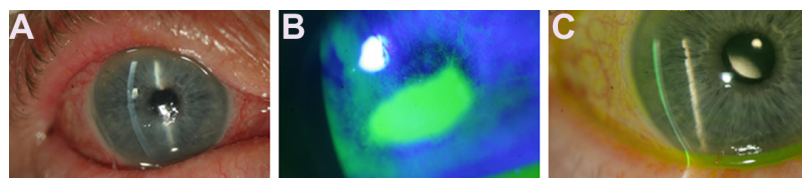

Figure I (A) Slit-lamp photograph of the right eye. Folds in Descemet's membrane could be appreciated, as well as mucous discharge, conjunctival hyperemia, and surface irregularities. (B) Fluorescein staining reveals a large epithelial defect with numerous surrounding punctate epithelial erosions. (C) Six weeks later, there was nearly complete resolution of Euphorbia toxicity.

cell and flare in this eye. Her vision in the left eye was $20 / 25$ and scant punctate epithelial erosions and trace cell and flare were seen on exam. Punctal plugs were placed as the patient had a poor tear film, as well as to promote epithelial healing with the tear's own growth factors. Gentamicin ointment was also initiated. On day 3 , the vision in the right eye improved to $20 / 200$ with improvement of the epithelial defect, although prominent stromal edema and Descemet's folds had developed. On day 5, although completely re-epithelialized, persistent corneal edema accompanied an elevated pressure of $28 \mathrm{mmHg}$ and continued mild anterior chamber inflammation. Brimonidine and nepafenac were started and her intraocular pressure decreased to $8 \mathrm{mmHg}$ the following day. Several weeks following this exposure, the patient had complete resolution, with vision of 20/20 in the right eye and 20/15 in the left eye (Figure 1C).

\section{Discussion}

The authors report a case of toxic keratopathy due to exposure to Euphorbia cyparissias (Figure 2). Untreated, the keratopathy associated with Euphorbia can be mild and self-limiting, or can be as severe as to cause blindness, especially when treatment is delayed and secondary infection is present. ${ }^{1-3}$

It is well documented that exposure to this plant may result in a keratopathy with a characteristic clinical course. ${ }^{4-6}$ Following contact with the sap of Euphorbia, there is burning, photophobia, and epiphora. Despite irrigation, this will often worsen. Exam may reveal punctate epithelial erosions, which will often enlarge to form a frank epithelial defect over the following day. Corneal edema is often present and an anterior uveitis may develop. Visual acuity may be only modestly reduced on presentation, but within the next day it may decrease to count fingers, much like the patient in this case.

The severity of keratitis from exposure to Euphorbia appears to depend somewhat on the exact species of plant involved. In Eke's clinical case series of ocular inflammation from several Euphorbia species, he describes the clinical

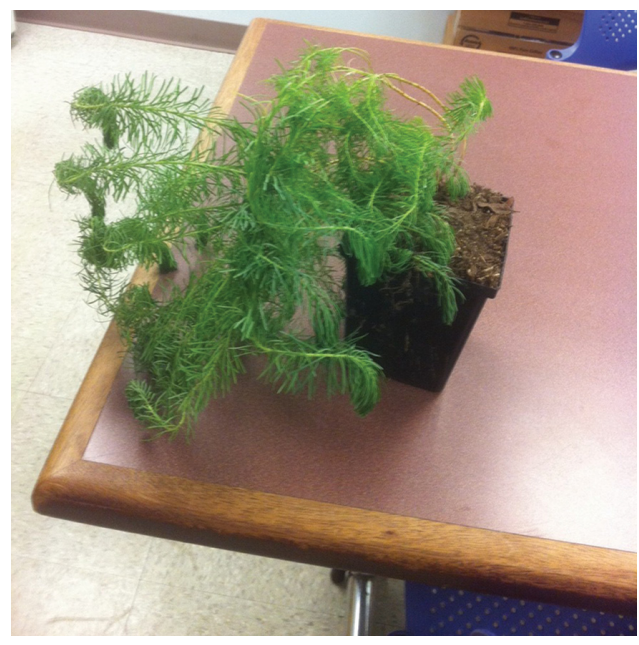

Figure 2 The plant, Euphorbia cyparissias, is often found in roadsides and fence rows. Notes: It is naturalized from Maine to Pennsylvania and from Illinois to Kansas and Colorado. The plant is alien to Europe. ${ }^{8}$

presentation according to plant species. ${ }^{5}$ The plant in this present case, E. cyparissias, was not described, however. Interestingly, the potency of E. cyparissias' sap is temporally dependent with toxicity decreasing during the months of April and May and peaking during August and September, coinciding with the month of exposure in this case. ${ }^{7,8}$

Another interesting report of Euphorbia toxicity involved the species Euphorbia lathyris. ${ }^{9}$ In that case, the authors reported that the patient's ocular $\mathrm{pH}$ was alkaline which resulted in alkaline chemical injury as a result of exposure to the plant sap. Given the similarities between the two cases, it appears that E. cyparissias, as in the present case, may act in much the same way as E. lathyris.

Treatment for patients exposed to Euphorbia sap includes measurement of the $\mathrm{pH}$ of the ocular surface and thorough irrigation. This patient had a likely combinedmechanism injury due to the noxious elements of the Euphorbia plant sap, as well as its basic pH. Fortunately, the patient did not develop any evidence of conjunctival injury or scarring from this exposure. Ophthalmic exam should also include eversion of the lids to ensure no foreign body or retained plant material is present. Topical antibiotics are recommended due to the high risk of infection in these cases. Cycloplegics and steroids have been described to have some utility in these cases and topical anti-inflammatory drops may also be useful. ${ }^{4-6}$ Punctal occlusion was found to be useful in this case in treating the patient's poor tear film and to promote reepithelialization. Close follow-up is warranted, with infection as the primary and most devastating complication from Euphorbia keratopathy with reports of some infections 
causing blindness. ${ }^{3}$ After infection has been ruled out in most corneal alkali injuries, steroids are warranted. In this case, given that the injury from Euphorbia is not only from its basic $\mathrm{pH}$, but from other components, and since the literature described that highest morbidity resulted from secondary infections, we elected to avoid steroids. Because of the close follow-up, we were able to appreciate a dramatic improvement in her condition, and fortunately steroids were ultimately not needed in this case.

In summary, exposure to the Euphorbia plant may cause an alkaline chemical injury with severe keratitis or keratouveitis. In this case, the history of exposure along with the patient's horticultural knowledge proved useful in identifying the cause and providing appropriate treatment. Eye care providers should include exposure to Euphorbia in the differential of any plant exposure, especially in autumn, causing marked keratitis and treatment should include measurement of the $\mathrm{pH}$ of the ocular surface and adequate irrigation.

\section{Acknowledgment}

The Department of Ophthalmology, University of North Carolina Hospitals, is a recipient of an unrestricted grant from Research to Prevent Blindness.

\section{Disclosure}

The authors have no financial or proprietary interest in materials and/or methods mentioned in this manuscript.

\section{References}

1. Grant WM, Schuman JS. Toxicology of the Eye, 4th ed. Springfield, IL: Charles C Thomas Publisher; 1993:680-682.

2. Duke-Elder S. System of Ophthalmology. London, UK: Kimpton; 1972;14:1185.

3. Sofat BK, Sood GC, Chandel RD, Mehrotra SK. Euphorbia royleana latex keratitis. Am J Ophthalmol. 1972;74:634-637.

4. Eke T. Euphorbia sap keratouveitis. Br J Ophthalmol. 1997;81(6):518.

5. Eke T, Al-Husainy S, Raynor MK. The spectrum of ocular inflammation caused by Euphorbia plant sap. Arch Ophthalmol. 2000;118(1): $13-16$.

6. Basak SK, Bakshi PK, Basu S, Basak S. Keratouveitis caused by Euphorbia plant sap. Indian J Ophthalmol. 2009;57(4):311-313.

7. Turner R. Wolf's milk. Euphorbias: A Gardener's Guide. Portland, OR: Timber Press; 1998:37.

8. Foster S, Caras R. Euphorbias. A Field Guide to Venomous Animals and Poisonous Plants. The Peterson Field Guide Series. New York, NY: Houghton Mifflin Company; 1994:142-143.

9. Ioannidis AS, Papageorgiou KI, Andreou PS. Exposure to Euphorbia lathyris latex resulting in alkaline chemical injury: a case report. $J$ Med Case Reports. 2009;3:115.
Clinical Ophthalmology

\section{Publish your work in this journal}

Clinical Ophthalmology is an international, peer-reviewed journal covering all subspecialties within ophthalmology. Key topics include: Optometry; Visual science; Pharmacology and drug therapy in eye diseases; Basic Sciences; Primary and Secondary eye care; Patien Safety and Quality of Care Improvements. This journal is indexed on

Submit your manuscript here: http://www.dovepress.com/clinical-ophthalmology-journal

\section{Dovepress}

PubMed Central and CAS, and is the official journal of The Society of Clinical Ophthalmology (SCO). The manuscript management system is completely online and includes a very quick and fair peer-review system, which is all easy to use. Visit http://www.dovepress.com/ testimonials.php to read real quotes from published authors. 